\title{
Corporate Social Responsibility and Firms' Financial Performance: A New Insight
}

\author{
Faisal Mahmood ${ }^{1, *} \mathbb{0}$, Faisal Qadeer ${ }^{1}$, Usman Sattar $\left.{ }^{2, *} \mathbb{(}\right)$, Antonio Ariza-Montes ${ }^{3,4} \mathbb{C}_{\text {, }}$ \\ Maria Saleem ${ }^{1}$ and Jaffar Aman ${ }^{5}$ \\ 1 Lahore Business School, The University of Lahore, Lahore 54000, Pakistan; drfaisalqadeer@gmail.com (F.Q.); \\ mariyasaleem1989@gmail.com (M.S.) \\ 2 Department of Social Work, College of Law and Political Science, Zhejiang Normal University, \\ Jinhua 321004, China \\ 3 Management Department, Universidad Loyola Andalucía, 14004 Córdoba, Spain; ariza@uloyola.es \\ 4 Facultad de Administración y Negocios, Universidad Autónoma de Chile, Santiago 425, Chile \\ 5 Postdoctoral Station of Public Administration and Sociology, Hohai University, Nanjing 210000, China; \\ amanjafar5@yahoo.com \\ * Correspondence: usman@zjnu.edu.cn (U.S.); faisalch62@gmail.com (F.M.); Tel.: +92-301-7122707 (F.M.)
}

Received: 29 March 2020; Accepted: 19 May 2020; Published: 21 May 2020

\begin{abstract}
A vast stream of literature has investigated the effect of corporate social responsibility (CSR) on firms' financial performance (FFP). However, this effect has remained unclear and undecided. For instance, numerous studies have examined the direct impact of firms' CSR initiatives on FFP, as well as examining various mechanisms to explain this relationship, but found inconsistent results. The indecisive results indicate that researchers lack consensus to define a mechanism to understand how and under what conditions CSR can affect FFP. Thus, this research aims to investigate how firms' CSR perception and disclosure derive accounting- (return on equity: ROE, earnings per share: EPS), market- (Tobin $Q$ ) and perception-based firms' financial performance through the mediation of competitive advantage and boundary conditions of family ownership and CEO narcissism. This research underpins the theoretical lens of the resource-based view to derive hypotheses. The research design employed in this study is quantitative, and the approach to theory development is deductive. Multi-method and multi-source data with temporal breaks are collected from 60 manufacturing firms listed on the Pakistan Stock Exchange (PSE). Primary data are collected from the top and middle managers, while secondary data are collected from the annual reports published by these firms. This research found that competitive advantage significantly mediated the indirect impact of perceived CSR and disclosure on FFP. Further, this relationship is strengthened by the contingencies of family ownership and CEO narcissism. Our results will assist the management of the firms to understand the implications of CSR perceptions and disclosure to derive a competitive advantage that ultimately translates into the firms' financial performance. Further, this research also revealed that managers should concentrate on the boundary conditions of family ownership and CEO narcissism as well. In particular, this research contributes to understand why CSR is viewed to have a strategic importance for the firms and how a resource-based perspective might be utilized in such endeavors.
\end{abstract}

Keywords: CSR perception and disclosure; financial performance; competitive advantage; family ownership; CEO narcissism 


\section{Introduction}

Academics in the field of management and finance consider corporate social responsibility (CSR) an indispensable topic of research, and several organizations are also actively getting engaged in CSR activities [1,2]. CSR investments provide various benefits to the firms that may enhance their financial performance, i.e., access to funds, low financing cost, an increase in stock returns, and customer loyalty [3]. Organizations' CSR initiatives also help them to cope with the uncertain business environment, such as today's dynamic, worldwide, and high-tech corporate era [4]. Moreover, CSR engagements assist organizations to achieve sustainable development as there is increasing demand for eco-friendly services and products. Accordingly, existing literature has investigated the concept of CSR in multiple ways and directions to establish the effect of firms' CSR activities on their employees' behaviors [1,5,6], human resources [7], customer satisfaction [8], firm reputation [9], creative and financial performance $[10,11]$. But the relationship between the firms' CSR engagements and firms' financial performance (FFP) remains a mainstream topic of research [3].

Thus, numerous studies have investigated the association of CSR with FFP in various viewpoints but have come up with vague and inconsistent findings. For instance, firms' CSR initiatives can provide more gains than the cost incurred, and thus, CSR activities increase firms' financial performance [12,13]. In contrast, the neoclassical economists claimed that firms could overlook such social costs and suggested a negative relationship [14]. So, no final consensus has been established so far, and the relationship of CSR with FFP is still debatable due to inconsistent results. Moreover, existing research has also argued that CSR and FFP relationships could be better explained through mediation mechanisms and boundary conditions, which are currently overlooked in most of the studies and can lead to biased results $[15,16]$. Existing literature has also suggested that CSR and FFP relationships must be examined through the mediation and contingencies instead of direct relationships. Xie [3] noted that existing research on CSR and FFP overlooked various factors that should be addressed in future studies. Moreover, existing studies also remained distinct regarding CSR and FFP measures [17]. A number of studies are confined to CSR perception or databases of CSR ratings such as the KLD database (Kinder, Lydenberg, and Domini). But there are only a few studies that measured CSR disclosure directly by taking data from the annual reports [8]. Similarly, firms' financial performance is also measured through distinctive measures, for example, accounting-, market-, and perception-based financial performance. But no study has considered all these multiple indicators of CSR and financial performance under one framework, and this may lead to inconclusive findings.

Thus, the present study aims to address the above-discussed discrepancies and extend the current debate of CSR and FFP relationship in numerous ways. For example, this research considers both CSR perceptions and disclosure. We also incorporate multiple indicators of firms' financial performance, such as perception-, accounting-, and market-based. Further, this study investigates the mediation mechanism of competitive advantage. Likewise, the present research analyzes the boundary conditions of family ownership and CEO narcissism on the CSR and FFP relationship with the mediation of competitive advantage. Accordingly, this research investigates some important and new questions: does competitive advantage mediate the CSR and FFP relationship? And when does the moderation of family ownership and CEO narcissism influence this relationship?

This study attempts to answer these questions through the theoretical lens of resource-based view following Barney [18], as firms create sustainable competitive advantage by effectually directing and operating their competencies and resources, which are exceptional, valuable, cannot be exactly imitated and no exact alternative is accessible [19]. Firms' CSR initiatives may assist them in developing some of these competencies and resources [20]. Thus, a resource-based view offers essential insights to explain CSR and firms' financial performance relationship; for instance, the effectiveness of resource-based view to study CSR perception and disclosure as it emphasizes on precise intangible resources like employees' skills, capabilities, culture, and reputation as these are challenging to copy or substitute [20].

The present study also investigated the contingencies of family ownership and CEO narcissism on the CSR and FFP association with the mediation mechanism of competitive advantage. For instance, 
family-owned firms may strengthen this relationship as these firms are more committed to long-term growth and consistent profits for the organization, and they show intense focus on organizational competitiveness, financial performance, and stakeholders' activities and interests [16]. Family-owned firms are more socially responsible for increasing their family image and their ties with stakeholders [21]. Whereas non-family owned firms mostly follow short-term goals and push firm management towards profit maximization rather than new product developments and distinctive competencies. Thus, family-owned firms will strengthen the CSR and FFP association with the mediation mechanism of competitive advantage than the non-family-owned firms. The contingency of CEO narcissism can also enhance this relationship as narcissistic individuals are showy and may be inclined towards CSR initiatives to fuel their positive self-image, which will benefit the organization to achieve sustainable competitive advantage and ultimately translate into superior financial performance. In particular, this research contributes to understanding why CSR is viewed to have strategic importance for the firms and how a resource-based perspective might be utilized in such endeavors.

The rest of the document comprises of literature background and hypotheses development in Section 2. Section 3 presents the materials and methods. Section 4 represents the data analysis and results. Finally, Section 5 enlightens discussions and conclusions.

\section{Literature Background and Hypotheses Development}

\subsection{Resource-Based View}

Firms can achieve sustainable competitive advantage by means or resources that are rare, worthwhile, inimitable, and organized to capture the value of customers as explained in the resource-based view (RBV) [18]. RBV models posit that they are the vital resources for firms' superior performance, and these resources should be rare, worthwhile, inimitable, and organized to capture the value of customers. The advocates of RBV suggest that it is valuable for organizations to use internal resources to exploit outside opportunities. RBV focuses on the resources that may help the organizations to achieve higher financial performance. These resources can be tangible and intangible and should be heterogeneous, immobile, and must have VRIO (valuable, rare, inimitable and organized to capture the value of customers) attributes to gain a competitive advantage.

\subsection{CSR and Firms' Financial Performance}

The concept of CSR is investigated from multiple perspectives, such as antecedents and outcomes of CSR. Aguinis [22] referred to CSR as the firms' context-specific activities and procedures which consider stakeholders' expectations and the triple bottom line of economic, social, and environmental performance. Despite various CSR perspectives, existing literature substantially considered the link of CSR with firms' financial performance (FFP). But the results remained inconsistent. For instance, Wang's [19] meta-analysis of 42 studies noted a positive CSR and FFP relationship. Similarly, other studies also documented that CSR positively affected FFP [13,23-25]. In contrast to the positive findings, a few studies also found a negative effect of CSR on FFP [20].

Some studies even enlighten the no or neutral association of CSR and FFP [26]. Moreover, existing studies also used distinctive measures of CSR and financial performance that can also cause inconsistent results. Thus, due to inconsistency in results, no final consent is established, so this debate is ongoing. This research argues by underpinning RBV that the CSR engagements of the organizations help them to develop resources that are exceptional, valuable, cannot be exactly imitated, and no exact alternative is accessible. Such as employees' skills and firms reputation as these are much challenging to copy or substitute $[19,20]$. Hence, we hypothesize that:

Hypothesis 1 (H1). CSR positively affects firms' financial performance. 


\subsection{Mediation of Competitive Advantage}

Competitive advantage is explained as the condition where competitive strategies are implemented by the organization, which is gaining benefits from these strategies on such level where its competitors are not able to copy nor to acquire benefits [27]. The resource-based view explained the importance of matchless capabilities and resources to attain a competitive benefit. Organizations can achieve competitive advantage by executing a worthwhile strategy that is not employed by the competitor at the same time. Competitive advantage is considered as the capabilities and resources of the organizations and is an essential factor for value creation [28].

Existing literature discussed the role of CSR activities in deriving competitive advantage and the effect of competitive advantage on FFP as well [29-31]. For example, CSR is essential for innovation, competitiveness, and sustainability for enterprises [28]. Marin [32] analyzed the causal effect of CSR on competitiveness and found that organizations achieve competitiveness through CSR. Moreover, CSR establishes the business resources which help to make positive stakeholder behavior, for instance, loyalty, commitment, satisfaction, donations, and purchase of products that improve its competitiveness and market value as well [8]. CSR is positively associated with a competitive advantage, which in turn translates to FFP $[28,33]$. Hence, the present study postulates that:

Hypothesis 2 (H2). Competitive advantage mediates the CSR and FFP relationship.

\subsection{Moderation of Ownership Structure}

The ownership structure is defined as the existence of family participants in the company's board of directors or the influence of family members in decision making. Carney [34] examined the link between corporate governance, family ownership, and competitive advantage and found that family-owned businesses value creation come through governance advantage. Shahzad [21] tested the moderation of ownership structure on the link between CSR and investment efficiency. They noted that family-owned businesses were more engaged in CSR activities in comparison with non-family-owned businesses. Likewise, Block [35] found that family firms give importance to the non-financial goals like CSR in developing a reputation, identity, family image, and extending resources.

Family-owned organizations engage in non-financial goals or consider non-family stakeholders to build their reputation for the longevity of their business [36]. Thus, it is possible to conclude that the effect of firms' CSR perception and disclosure on competitive advantage becomes stronger when the firm is family-owned. In other words, when firms are family-owned, then their CSR initiatives tend to provide more competitive advantage. As these firms are more committed to long-term growth and consistent profits of the organization, they show intense concentration with organizational competitiveness [28] and are more socially responsible for increasing their family image and their ties with stakeholders [21]. Hence, we hypothesize that:

Hypothesis 3 (H3). Family ownership moderates the CSR and FFP relationship mediated by competitive advantage, and the effect is strengthened when family ownership is high than when it is low.

\subsection{Moderation of CEO Narcissism}

Narcissistic individuals consider themselves exceptional, distinctive, and overstate their abilities and achievements [37]. The existing literature has investigated both the negative and positive roles of narcissist leaders to influence organizational strategies and outcomes like risky initiative, excessive research, and development, innovations, and CSR investments. Tang [38] analyzed the association of CEO narcissism with CSR. According to these authors, narcissist CEOs utilize CSR as a tool for positive self-perception. Moreover, narcissist CEOs tend towards CSR initiatives for their personal admiration, media attention, and personal exhibitions. Using a sample of Fortune 500 CEOs, Petrenko [39] documented 
the positive link between CSR and CEO narcissism. CEO narcissism plays an essential part in enhancing the firm's CSR initiatives. Therefore, the effect of firms' CSR perceptions and disclosure on competitive advantage becomes stronger when the $\mathrm{CEO}$ is narcissistic. As narcissistic individuals are showy, they may be inclined to use CSR initiatives to fuel their positive self-image; narcissistic CEOs may also highlight the CSR actions of their organizations to gain reputation. Accordingly, we hypothesize that:

Hypothesis 4 (H4). CEO narcissism moderates the CSR and FFP relationship mediated by competitive advantage, and the effect is strengthened when CEO narcissism is high than when it is low.

Figure 1 presents all the hypothesized relationships on the direct and indirect CSR and FFP relationship with the mediation of competitive advantage and moderation of family ownership and CEO narcissism. RBV is used to derive all hypotheses. CSR is presented by perception and disclosure, and similarly, FFP is considered by perception-, market-, and accounting-based indicators.

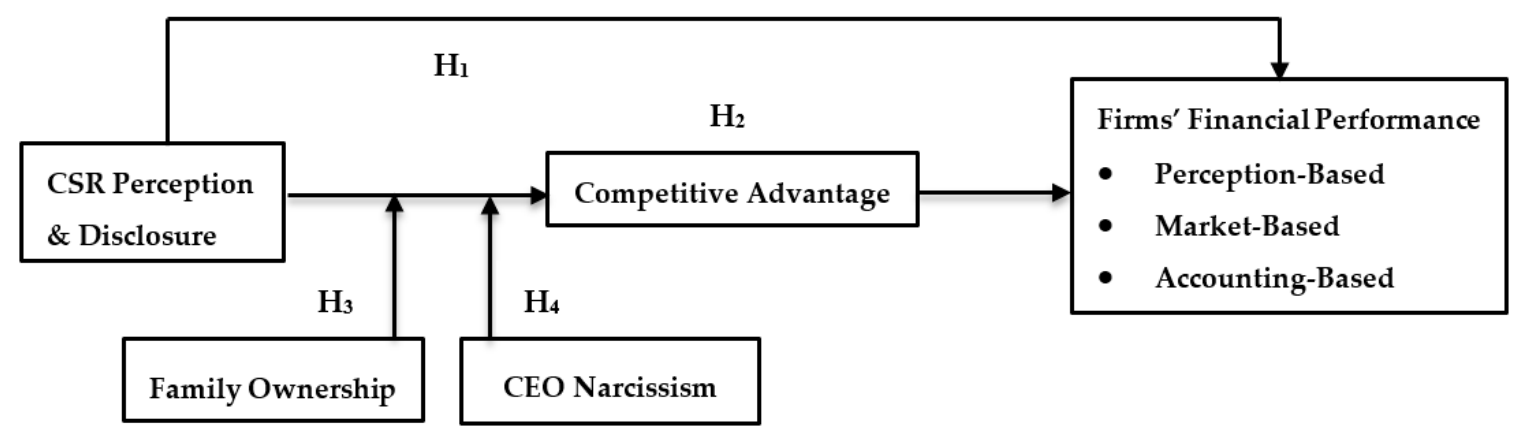

Figure 1. Hypothesized Model.

\section{Materials and Methods}

\subsection{Data Collection and Sample}

The present study utilized a cross-sectional quantitative research design with a deduction approach to theory development. This is a multi-method and multi-source research with firms as a unit of analysis. This research collected primary data by using survey strategy and secondary data from the annual reports. This study followed a two-stage sampling process. In the sample selection process, we did not consider the firms that had not reported CSR initiatives or activities on their annual reports and whose data was not available. Thus, in the first stage, after prudentially considering the objectives of this research, we selected 89 manufacturing firms listed at PSE, which are engaged in CSR activities. These firms contribute to employees' benefits, healthcare foundations, and free education and also stipulate their CSR intents on their authorized websites.

In the second stage, we made requests to the top management of these selected firms for the primary data collection by clearly communicating the purpose of our research. Eventually, we received confirmation from 60 firms. We promised to keep anonymity and privacy and signed an ethics agreement with these firms. After that, we visited the human resource (HR) management of each firm. HR had already been informed about our research by the top management, and they provided us the complete details of permanent employees. Primary data were collected from multiple sources, including top managers, middle managers, and finance managers. With HR support, we identified 325 top managers, 225 middle managers, and 250 finance managers. After that, we conducted multiple self-administrative surveys to collect data from multiple sources with temporal breaks over six weeks from December 2019 to January 2020. Podsakoff [40] explained that single-time data collection in primary research could cause common method biases. Thus, to minimize these biases, the data were collected in two waves about three weeks apart. Time-lagged designed is also referred to as a desirable design in most of the CSR research [41,42]. 
In the first wave, we conducted our Survey 1 and distributed 300 self-administrated questionnaires among randomly selected top managers (five top managers each firm) to rate their CSR perception and their CEO narcissism; 123 (41\%) usable questionnaires were collected. This response rate seems low at first glance. However, a similar response rate is also reported in numerous CSR studies who collected data from top managers such as Mishra [43] and Saeidi et al. [8] who reported $10 \%$ and $17 \%$, respectively. In Survey 2, we distributed 180 questionnaires among randomly selected middle managers (three middle managers each firm) to collect data on competitive advantage and received $106(58.8 \%)$ useable questionnaires.

In the second wave, Survey 3 was conducted to collect data from 200 randomly selected finance managers (five finance managers each firm) on their perception of firms' financial performance and family ownership; we obtained 131 (65.5\%) completed questionnaires. All the participants were granted anonymity, privacy, and no effect of their responses on their performance, which was also guaranteed to minimize biases such as social desirability Podsakoff [40]. Our final data set consists of 340 completed questionnaires with a final response rate of $50 \%$ in all facets.

The secondary data was collected regarding CSR disclosure and FFP (Tobin Q, EPS, and ROE) PSE, the central bank of Pakistan, annual and sustainability reports available at the official website of each firm. CSR disclosure data were collected for 2018 and one-year-lagged financial performance for 2019. At first sight, this period seems short, but the CSR disclosure data for previous years were not available for a number of firms because reporting CSR activities or issuing sustainability reports is in its beginning in Pakistan, thus restricting us from collecting recent data.

\subsection{Measures}

This research incorporates well-established measures and uses both primary and secondary measures of CSR and financial performance. Primary data is collected on CSR perceptions by using measures developed by Maignan [44], a 29-item Likert-type scale (5 for strongly agree (SA) to 1 for strongly disagree (SD)). The sample items are: "We continually improve the quality of our products", "We are recognized as a trustworthy company". The high reliability of the scale is shown by the Cronbach's alpha value of 0.92 . Existing research has extensively documented various databases, for instance, Kinder, Lydenberg, and Domini, Fortune's Most Admired Companies, to measure CSR by using secondary data. But no such databases are available in developing countries such as Pakistan. Thus, existing studies have constructed a CSR disclosure index by taking data from annual and sustainability reports. For instance, Khan [45] developed a 20-item index to measure CSR disclosures. A binary procedure was applied to rate the presence of required information in the firm, and the index is calculated by the ratio of actual score to attainable score for a firm. Blasi [46] constructed a CSR disclosure index based on firms' involvement in community, environment, employee relations, human rights, governance, and management diversity. Kansal [47] also constructed the CSR index by considering environmental factors, minority rights, and annual reports of the firms with CSR disclosure. Yuen [48] used firm engagements like employee education, charity, reporting standards, environmental involvement, and customer relations to develop the CSR disclosure index. Malik [49] calculated the CSR disclosure index by firms' engagements with employee, community, and customer relations, and environmental involvement.

This research constructed the CSR disclosure index along with five dimensions, including community involvement, environmental involvement, employee information, value-added information, and product and service information, similar to Khan [45]. The index comprised of 20 items and represents the extent to which firms reveal their CSR undertakings in the annual reports. A binary method was applied in which a firm was awarded one in case an item incorporated in the index was exposed, otherwise the firm was awarded zero. Moreover, a firm was not penalized for a zero if the index item was not related to it, and this was done after reading the complete annual report. The index is derived by estimating the ratio of the score achieved by a firm to the highest possible score (20). The index for every firm is measured by dividing the attained score to the highest attainable score for 
that firm Galvin [50]. We assessed the index's internal consistency by making use of Cronbach's alpha, which was 0.81 .

Firms' financial performance is measured through perception-, market-, and accounting-based indicators. Perception of financial performance is measured through the Saeidi et al. [8] seven-item scale $(1=$ Much worse to $5=$ Much better). The sample items included: "In the last three years, our firm has performed worse/better than the major competitors in the industry regarding growth in sales." We measured accounting- and market-based indicators of FFP by using the secondary data from the annual reports. In the existing literature, competitive advantage is measured by using various scales. For instance, Zho [51] measured competitive advantage along with financial and market dimensions by following existing scales, such as those developed by Protogerou [52] and Chen [53]. This study measured competitive advantage by using Chen's [54] eight-item five-point Likert scale $(1=\mathrm{SD}$ to $5=\mathrm{SA})$. This measure explained the firm's competitive advantage by concentrating on cost-effectiveness, product quality, innovation and research, managerial capability, growth, profitability, position, and image of the company in contrast to competitors. The sample items include: "The corporate image of the firm is better than that of the competitors", "The Company is more capable of R\&D and innovation than the competitors". CEO narcissism is measured by using the Resick [55] eight-item scale $(1=$ Very to $5=$ Not at all). The sample items consist of: "How accurately the word arrogant describes your CEO". Family ownership was considered as a binary variable that takes the value of one in case of family ownership (presence of family members in the firm's board of directors), otherwise zero for non-family-owned firms. Moreover, control variables incorporated in this research were respondents' gender, education, age, tenure with organization, firm size and leverage.

\subsection{Analytical Strategy}

This research employed contemporary data analysis procedures. We conducted preliminary data analysis to test for accuracy, outliers, missing values, normality, summary, and inferential statistics in SPSS. We also performed a confirmatory factor analysis to examine construct validity and model fitness indicators by making use of AMOS. Model fitness is assessed by commonly used indices, such as chi-square/degrees of freedom, root mean square error approximation (RMSEA), standardized root mean square residual (SRMR), Tucker-Lewis index (TLI) and comparative fit index (CFI). The acceptable values for these indicators ranged from $<2$ for $X^{2} / \mathrm{d} f$; the value for RMSEA and SRMR must be less than 0.08 , and it should be greater than 0.90 for CFI and TLI [56]. Reliability of the constructs was measured through Cronbach's alpha, and composite reliability and further discriminant validity were established through average variance extracted. Further, to investigate the existence of common method biases, we performed Harman's one-factor test because of the self-reported surveys and the cross-sectional nature of data, and found no such issue in this research. Finally, structural equation modeling (SEM) was used to find direct and indirect effects. CSR perception, competitive advantage, and perceived financial performance were aggregated to firm-level by following Chan's [57] typology of the direct consensus model. As top managers' perception of CSR, middle managers' ratings of competitive advantage and finance managers' perception of financial performance were aggregated from individual-level responses to firm-level.

Chan [57] and Farh [58] explained that such aggregation is possible. Further, to found this consensus to aggregate individual responses to the firm-level, we computed RWG $(j)$ for perceived CSR (0.69), competitive advantage (0.78), and perceived financial performance (0.83) following Preacher et al. [59]. We found that these values were within the acceptable range [60,61] and validated the aggregation. This decision is also consistent with other studies that have also made such aggregation $[5,62,63]$. Further, existing studies noted the endogeneity bias while investigating direct CSR and firms' financial performance relationship. Endogeneity bias presents a crucial concern to analyze cause and effect relations, and failure to control endogeneity bias may result in misleading and counterfeit findings [10,64]. Javeed [10] documented that endogeneity is a common issue in most 
panel data analysis due to the correlation of explanatory variables with the error term in regression that causes biased findings.

Existing literature has found various sources of endogeneity, such as simultaneous causality, omitted variable, and errors in variables $[64,65]$. Simultaneous causality is the most common cause of endogeneity bias in CSR and firms' financial performance relationship. Exiting research addressed the endogeneity issue with various remedies, such as the use of control variables, instrumental variables (two-stage least square, three-stage least square), high moment, latent instrumental variable, matching method, generalized method of moments (GMM), Heckman two-step procedure and lagging independent and dependent variable $[9,63]$. Each of these remedies has its implication; for example, GMM is suitable and frequently used to deal with endogeneity issues in panel data and lagged variables for simultaneous endogeneity bias. The present research employs a lagged variable technique to deal with endogeneity concerns while examining the direct CSR and FFP relationship. This is a non-statistical remedy to mitigate the possible endogeneity issue and consider in advance at the time of the research design stage by adopting a time-lagged measurement of the explanatory and dependent variables. Accordingly, we lagged the dependent variable by one period as the data for CSR disclosure was collected for 2018 with one-year-lagged financial performance (market and accounting-based indicators) data for 2019, and this is also consistent with other studies that alleviated endogeneity bias by employing the lagged variable method [10,66-68].

\section{Data Analysis and Results}

\subsection{Descriptive Analysis}

Table 1 explains the construct reliability, validity, and descriptive statistics, and the results specified no issue of validity and reliability.

Table 1. Reliability and Descriptive Statistics.

\begin{tabular}{lcccccc}
\hline & Item & Alpha & AVE & CR & Mean & SD \\
\hline Perceived Financial Performance & 7 & 0.76 & 0.50 & 0.94 & 4.00 & 0.41 \\
Perceived CSR & 29 & 0.92 & 0.51 & 0.89 & 4.30 & 0.31 \\
Competitive Advantage & 8 & 0.71 & 0.61 & 0.79 & 4.10 & 0.57 \\
CEO Narcissism & 8 & 0.59 & 0.77 & 0.77 & 4.00 & 0.41 \\
Family Ownership & 2 & 0.62 & 0.70 & 0.69 & 0.46 & 0.20 \\
Tobin Q & & & & & 2.03 & 1.55 \\
Earnings per Share & & & & & 34.01 & 18.0 \\
Return on Equity & & & & 25.09 & 40.1 \\
CSR Disclosure & & & & 0.71 & 0.12 \\
\hline
\end{tabular}

Notes: Alpha stands for Cronbach's alpha, AVE represents average variance extracted, CR is the composite reliability, and SD signifies the standard deviation.

The Cronbach's alpha is within the acceptable range values for all the constructs, as recommended by Nunnally [69]. For instance, 0.76 for perceived financial performance, 0.92 for perceived CSR, 0.71 for competitive advantage, 0.59 and 0.62 for CEO narcissism and family ownership, respectively. The data were also tested for composite reliability and validity, and there was no such issue. Our results were in an acceptable range; for example, CR is above 0.70, and AVE is 0.50 for all the constructs [56]. Further, the mean and standard deviation values (SD) were also satisfactory. For instance, the CSR perception mean value was 4.30 , which might seem high because the firms considered in this research are known for their CSR initiatives, whereas the values for standard deviation were also within the normal range. But standard deviation values were high for accounting-based indicators as the firms with distinctive size and sectors were considered.

Table 2 represented the bivariate correlation results among the studied variables. We found that no variable is exactly or strongly correlated with other variables. Thus, there is no multicollinearity 
problem, and the correlation coefficients are also in the supposed directions. Thus, we found a statistically significant positive relationship of CSR perception with perceived financial performance $(0.11, \mathrm{p}<0.05)$, Tobin $\mathrm{Q}(0.23, \mathrm{p}<0.01)$, earning per share $(0.17, \mathrm{p}<0.01)$ and return on equity $(0.20, \mathrm{p}<0.01)$. Similarly, CSR disclosure was also positively and significantly related to perceived financial performance $(0.21, \mathrm{p}<0.01)$, return on equity $(0.20, \mathrm{p}<0.01)$, Tobin $\mathrm{Q}(0.04$, insignificant $)$ and earning per share (0.05, insignificant). We found that perceived CSR and competitive advantage were significantly and positively related $(0.25, \mathrm{p}<0.01)$, as well as CSR disclosure and competitive advantage $(0.24, \mathrm{p}<0.01)$. Competitive advantage and perceived financial performance positively and significantly correlated $(0.15, \mathrm{p}<0.01)$, whereas Tobin $\mathrm{Q}(0.04$, insignificant), earning per share $(0.09$, insignificant) and return on equity $(0.02$, insignificant) remained statistically insignificant.

Table 2. Inferential Statistics.

\begin{tabular}{|c|c|c|c|c|c|c|c|c|c|c|}
\hline & & 1 & 2 & 3 & 4 & 5 & 6 & 7 & 8 & 9 \\
\hline 1. & Perceived FFP & 1 & & & & & & & & \\
\hline 2. & Perceived CSR & $0.11^{* *}$ & 1 & & & & & & & \\
\hline 3. & Competitive Advantage & $0.15 *$ & $0.25 *$ & 1 & & & & & & \\
\hline 4. & CEO Narcissism & 0.57 * & 0.11 & 0.05 & 1 & & & & & \\
\hline 5. & Family Ownership & 0.08 & 0.22 & $0.30 * *$ & 0.08 & 1 & & & & \\
\hline 6. & Tobin Q & 0.05 & $0.23 *$ & 0.04 & 0.05 & 0.00 & 1 & & & \\
\hline 7. & Earnings per Share & 0.06 & 0.17 * & 0.09 & 0.06 & 0.02 & 0.16 & 1 & & \\
\hline 8. & Return on Equity & 0.07 & $0.20 * *$ & 0.02 & 0.06 & 0.11 & $0.28 *$ & $0.43 *$ & 1 & \\
\hline 9. & CSR Disclosers & 0.21 * & 0.04 & $0.24^{*}$ & 0.21 & 0.00 & 0.04 & 0.05 & 0.20 * & 1 \\
\hline
\end{tabular}

Notes: FFP stands for firms' financial performance, ${ }^{*} \mathrm{p}<0.01,{ }^{* *} \mathrm{p}<0.05$.

\subsection{Hypotheses Testing}

Table 3 and Figure 2 report the direct effects among the variables. Model fit indices were $\mathrm{X}^{2} / \mathrm{d} f=2.31$, RMSEA $=0.035$, SRMR $=0.017, \mathrm{CFI}=0.98$ and TLI $=0.97$.

Table 3. Summary of Direct Effects.

\begin{tabular}{lccc}
\hline & Estimates & p-Value & Remarks \\
\hline Perceived CSR $\rightarrow$ Perceived Financial Performance & $0.18^{* *}$ & 0.05 & $\mathrm{H}_{1:}$ Supported \\
Perceived CSR $\rightarrow$ Tobin Q & $1.63^{* *}$ & 0.03 & $\mathrm{H}_{1}$ : Supported \\
Perceived CSR $\rightarrow$ Earning Per Share & $0.40^{* *}$ & 0.04 & $\mathrm{H}_{1}$ : Supported \\
Perceived CSR $\rightarrow$ Return on Equity & $0.30^{*}$ & 0.03 & $\mathrm{H}_{1:}$ Supported \\
CSR Disclosers $\rightarrow$ Perceived Financial Performance & $0.83^{*}$ & 0.02 & $\mathrm{H}_{1:}$ Supported \\
CSR Disclosers $\rightarrow$ Tobin Q & $0.85^{* *}$ & 0.05 & $\mathrm{H}_{1}$ : Supported \\
CSR Disclosers $\rightarrow$ Earning Per Share & $0.21^{* *}$ & 0.05 & $\mathrm{H}_{1}$ : Supported \\
CSR Disclosers $\rightarrow$ Return on Equity & $0.99^{*}$ & 0.01 & $\mathrm{H}_{1}$ : Supported \\
Perceived CSR $\rightarrow$ Competitive Advantage & $1.29^{*}$ & 0.03 & \\
CSR Disclosers $\rightarrow$ Competitive Advantage & $0.45^{* *}$ & 0.05 & \\
Competitive Advantage $\rightarrow$ Perceived Financial Performance & $0.02^{* *}$ & 0.05 & \\
Competitive Advantage $\rightarrow$ Tobin Q & 0.12 & $\mathrm{~ns}$ & \\
Competitive Advantage $\rightarrow$ Earning Per Share & 0.37 & $\mathrm{Ns}$ & \\
Competitive Advantage $\rightarrow$ Return on Equity & 0.29 & $\mathrm{Ns}$ & \\
\hline
\end{tabular}

${ }^{*} \mathrm{p}<0.01,{ }^{* *} \mathrm{p}<0.05$ Disclosure. 


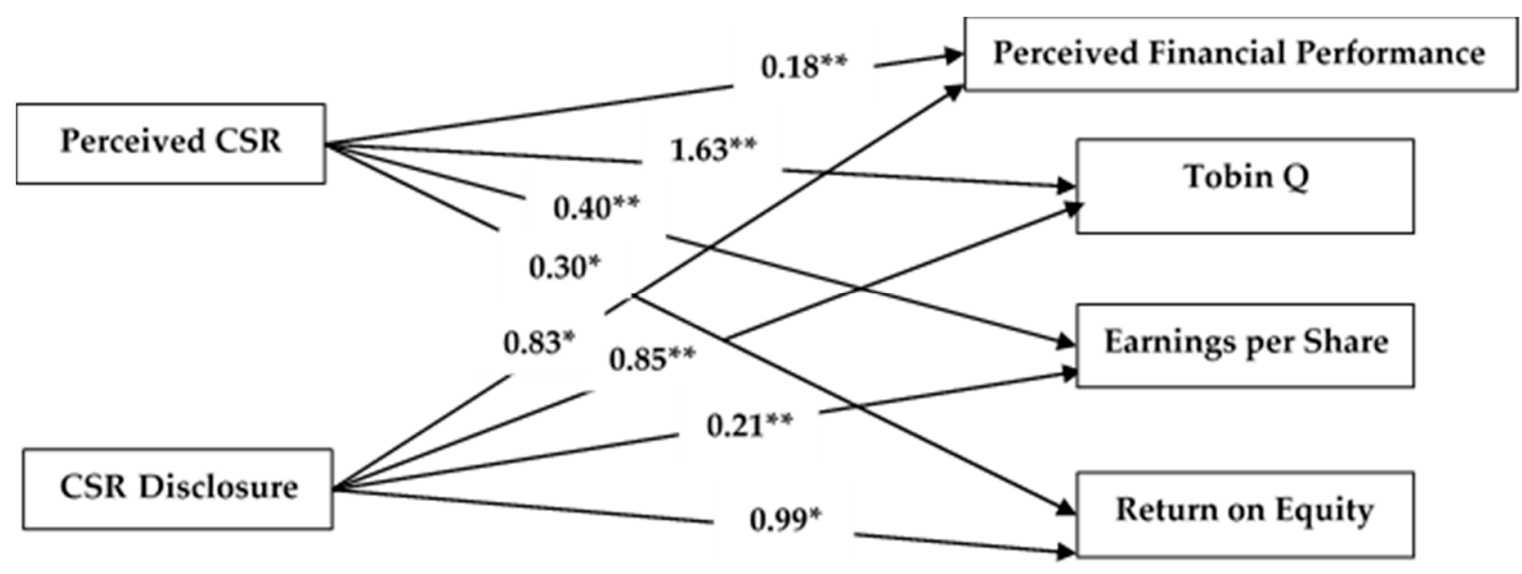

Figure 2. Direct Effects, ${ }^{*} \mathrm{p}<0.01,{ }^{* *} \mathrm{p}<0.05$.

In Hypothesis 1, we stated that CSR positively affects firms' financial performance. Accordingly, we tested the effect of multiple indicators of CSR (CSR perception and disclosure) on multiple indicators of firms' financial performance (perceived financial performance, Tobin $Q$ as market-based, earning per share, and return on equity as accounting-based). We found that perceived CSR has a statistically significant positive effect on perceived financial performance $(0.18, p=0.05)$, Tobin $Q(1.63, p=0.03)$, earning per share $(0.40, p=0.04)$ and return on equity $(0.30, p=0.03)$. Thus, by keeping all other things constant, with a one-unit increase in CSR perceptions, perceived financial performance, Tobin Q, EPS, and ROE increase by 0.18 units, 1.63 units, 0.40 units, and 0.30 units, respectively. We also noted a positive and significant effect of CSR disclosure on perceived financial performance $(0.83, p=0.02)$, Tobin $Q(0.85$, $p=0.05)$, earning per share $(0.21, p=0.05)$ and return on equity $(0.99, p=0.01)$. Thus, by keeping all other things constant, with a one-unit increase in CSR disclosure, perceived financial performance, Tobin $Q$, EPS, and ROE increase by 0.83 units, 0.85 units, 0.21 units, and 0.99 units, respectively.

Therefore, our Hypothesis 1 is supported across all multiple indicators of CSR and firms' financial performance. Further, we also tested the direct effect of perceived CSR and CSR disclosure on competitive advantage and the direct effect of competitive advantage on perceived financial performance, Tobin Q, EPS, and ROE. We found that CSR perception positively and significantly affected competitive advantage $(1.29, \mathrm{p}=0.03)$ and CSR disclosure on competitive advantage $(0.45$, $p=0.03$ ). Thus, with a one-unit increase in CSR perception and disclosure, firms' competitive advantage increases by 1.29 units and 0.45 units, respectively. Likewise, the competitive advantage was also found to have a significant and positive effect on perceived financial performance $(0.02, \mathrm{p}=0.05)$. However, it had a positive and insignificant effect on Tobin $\mathrm{Q}(0.12, \mathrm{p}=0.07)$, EPS $(0.37, \mathrm{p}=0.065)$, and $\operatorname{ROE}(0.29, \mathrm{p}=0.495)$.

Table 4 and Figure 3 represent the indirect effects of perceived CSR and CSR disclosure on perceived financial performance, Tobin Q, EPS, and ROE through the mediation of competitive advantage. We stated in Hypothesis 2 that the CSR and FFP relationship is mediated by competitive advantage. Our results indicated that competitive advantage significantly mediated the relationship of perceived CSR and Tobin Q 0.15 (95\% CI [0.05, 0.19]), earning per share 0.48 (95\% CI [0.05, 0.19]), return on equity 0.37 (95\% CI [0.05, 0.19]), but it remained statistically insignificant for perceived financial performance $0.02(95 \%$ CI $[-0.01,0.04])$. Thus, this supported our Hypotheses 2 except for the association of perceived CSR with a perceived financial performance by the mediation of competitive advantage. Moreover, we also noted the mediation of competitive advantage between CSR disclosure and EPS 0.17 (95\% CI [0.22, 0.41]) and ROE 0.13 (95\% CI [0.03, 0.59]). However, this relationship remained statistically insignificant for perceived financial performance, and Tobin $\mathrm{Q}$ and our Hypothesis 2 is not supported. In particular, competitive advantage mediated the relationship of perceived CSR and market-based and accounting-based financial performance indicators. Likewise, 
we also found the mediation of competitive advantage between CSR disclosure and accounting-based financial performance.

Table 4. Summary of Mediation Effects.

\begin{tabular}{lccc}
\hline & Estimates & 95\% CI & Remarks \\
\hline Perceived CSR $\rightarrow$ CA $\rightarrow$ PFP & 0.02 & {$[-0.01,0.04]$} & ns \\
Perceived CSR $\rightarrow$ CA $\rightarrow$ Tobin Q & $0.15^{*}$ & {$[0.05,0.19]$} & $\mathrm{H}_{2:}$ Supported \\
Perceived CSR $\rightarrow$ CA $\rightarrow$ EPS & $0.48^{*}$ & {$[0.21,0.77]$} & $\mathrm{H}_{2:}$ Supported \\
Perceived CSR $\rightarrow$ CA $\rightarrow$ ROE & $0.37^{*}$ & {$[0.12,0.55]$} & $\mathrm{H}_{2:}$ Supported \\
CSR Disclosure $\rightarrow$ CA $\rightarrow$ PFP & 0.009 & {$[-0.11,0.02]$} & ns \\
CSR Disclosure $\rightarrow$ CA $\rightarrow$ Tobin Q & 0.05 & {$[-0.16,0.04]$} & ns \\
CSR Disclosure $\rightarrow$ CA $\rightarrow$ EPS & $0.17^{* *}$ & {$[0.22,0.41]$} & $\mathrm{H}_{2:}$ Supported \\
CSR Disclosure $\rightarrow$ CA $\rightarrow$ ROE & $0.13^{* *}$ & {$[0.03,0.59]$} & $\mathrm{H}_{2:}$ Supported \\
\hline
\end{tabular}

Notes: ${ }^{*} \mathrm{p}<0.01,{ }^{* *} \mathrm{p}<0.05, \mathrm{CA}=$ Competitive Advantage, $\mathrm{PFP}=$ Perceived Financial Performance, EPS = Earnings per Share, $\mathrm{ROE}=$ Return on Equity.

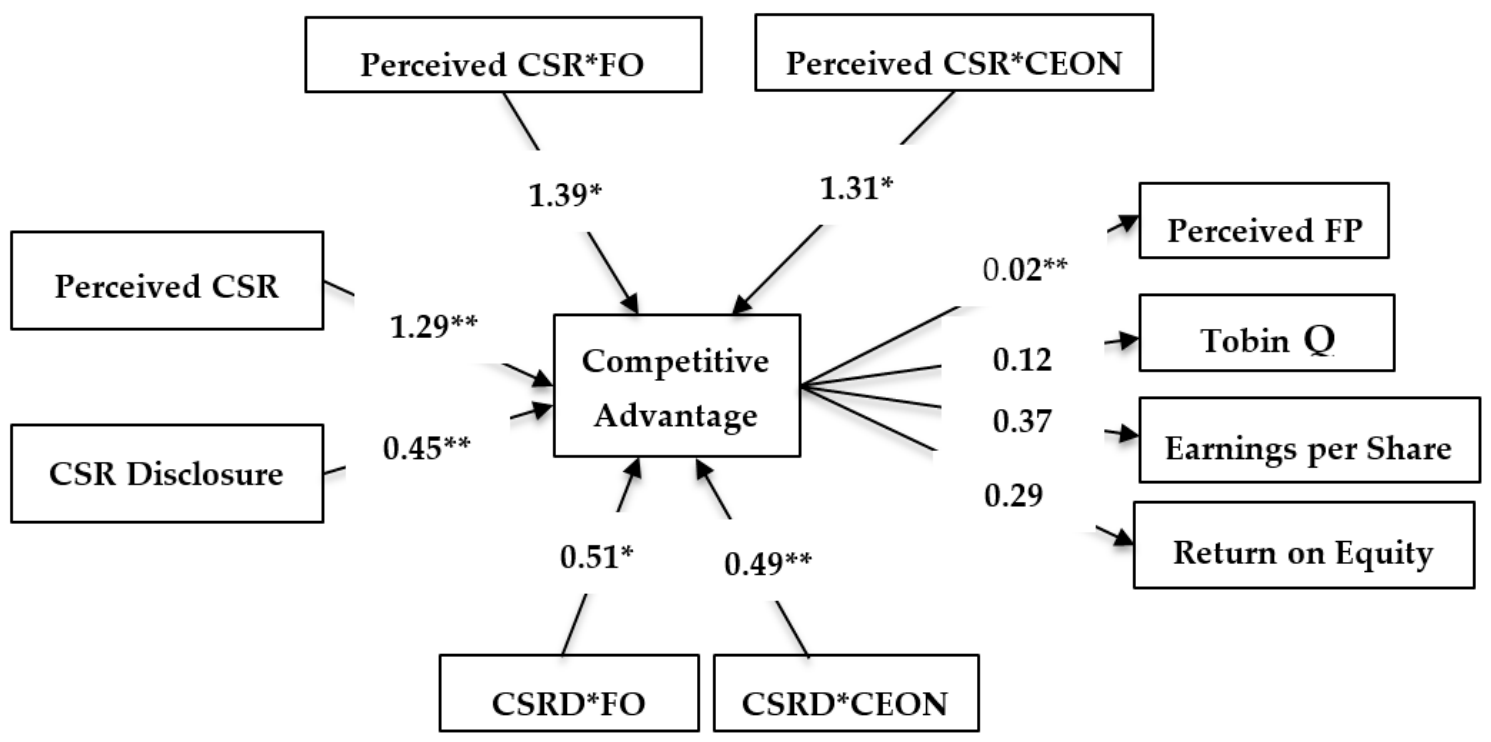

Figure 3. Indirect Effects, ${ }^{*} \mathrm{p}<0.01,{ }^{* *} \mathrm{p}<0.05$.

Table 5 and Figure 3 reported the moderation of family ownership on the relationship of CSR perception and disclosure with firms' perceived financial performance, Tobin Q, EPS, and ROE through the mediation of competitive advantage. In Figure 3, CSRD stands for CSR disclosure, and FO represents family ownership. Further, to investigate the moderation of family ownership on the above-discussed relationship, we examined the interaction effect of CSR perception and family ownership, and CSR disclosure and family ownership on the competitive advantage.

We found a statistically significant positive effect on competitive advantage for both CSR perception and disclosure (Perceived CSR ${ }^{*} \mathrm{FO}=1.39$ ), $95 \% \mathrm{CI}[0.88,2.99]$ and (CSR disclosure $\left.{ }^{*} \mathrm{FO}=0.51\right), 95 \% \mathrm{CI}$ $[0.13,2.68]$. In our third hypothesis, we stated that family ownership moderates the CSR and FFP relationship through the mediation of competitive advantage. Accordingly, we found that family ownership strengthened this relationship. For example, the impact of perceived CSR on perceived financial performance mediated through competitive advantage is strengthened by family ownership $0.03(95 \%$ CI $[0.01,0.05])$ as previously as discussed in Table 4 ; it was statistically insignificant 0.02 $(95 \%$ CI $[-0.01,0.04])$. 
Table 5. Moderation of Family Ownership.

\begin{tabular}{|c|c|c|c|}
\hline & Estimates & $95 \% C I$ & Remarks \\
\hline Perceived CSR ${ }^{*} \mathrm{FO} \rightarrow \mathrm{CA}$ & $1.39 *$ & {$[0.88,2.99]$} & \\
\hline CSR Disclosure ${ }^{*} \mathrm{FO} \rightarrow \mathrm{CA}$ & $0.51 *$ & {$[0.13,0.68]$} & \\
\hline Perceived CSR $*$ FO $\rightarrow$ CA $\rightarrow$ PFP & $0.03 * *$ & {$[0.01,0.05]$} & $\mathrm{H}_{3}:$ Supported \\
\hline Perceived CSR ${ }^{*} \mathrm{FO} \rightarrow \mathrm{CA} \rightarrow$ Tobin $\mathrm{Q}$ & $0.17 *$ & {$[0.02,0.21]$} & $\mathrm{H}_{3}:$ Supported \\
\hline Perceived CSR ${ }^{*} \mathrm{FO} \rightarrow \mathrm{CA} \rightarrow$ EPS & 0.51 * & {$[0.14,0.68]$} & $\mathrm{H}_{3}$ : Supported \\
\hline Perceived CSR*FO $\rightarrow \mathrm{CA} \rightarrow \mathrm{ROE}$ & 0.40 * & {$[0.09,0.11]$} & $\mathrm{H}_{3}$ : Supported \\
\hline CSR Disclosure ${ }^{*} \mathrm{FO} \rightarrow \mathrm{CA} \rightarrow$ PFP & 0.01 & {$[-0.01,0.03]$} & ns \\
\hline CSR Disclosure ${ }^{*} \mathrm{FO} \rightarrow \mathrm{CA} \rightarrow$ Tobin $\mathrm{Q}$ & 0.06 & {$[-0.14,0.03]$} & ns \\
\hline CSR Disclosure ${ }^{*} \mathrm{FO} \rightarrow \mathrm{CA} \rightarrow$ EPS & $0.19^{* *}$ & {$[0.19,0.32]$} & $\mathrm{H}_{3}$ : Supported \\
\hline CSR Disclosure ${ }^{*} \mathrm{FO} \rightarrow \mathrm{CA} \rightarrow \mathrm{ROE}$ & $0.15^{* *}$ & {$[0.01,0.47]$} & $\mathrm{H}_{3}$ : Supported \\
\hline
\end{tabular}

${ }^{*} \mathrm{p}<0.01,{ }^{* *} \mathrm{p}<0.05, \mathrm{FO}=$ Family Ownership, $\mathrm{CA}=$ Competitive Advantage, PFP = Perceived Financial Performance, EPS $=$ Earnings Per Share, ROE $=$ Return On Equity.

Moreover, we also find that relationships of perceived CSR with Tobin Q, EPS and ROE mediated by competitive advantage are strengthened with the moderation of family ownership: 0.17 (95\% CI $[0.02,0.21]), 0.51(95 \%$ CI $[0.14,0.68]), 0.40$ (95\% CI [0.09, 0.11]), respectively. This supported our Hypothesis 3. However, the indirect effects of CSR disclosure on perceived financial performance and Tobin Q mediated by competitive advantage remained statistically insignificant: 0.01 ( $95 \%$ CI [-0.01, $0.03]), 0.06$ (95\% CI [-0.14, 0.03]). Meanwhile, family ownership strengthened the indirect effect of CSRD on EPS and ROE mediated by competitive advantage: 0.19 (95\% CI [0.19, 0.32]), 0.15 (95\% CI $[0.01,0.47])$. These results supported Hypothesis 3 as well.

Further, to better understand the moderation of family ownership on perceived CSR and competitive advantage, and CSR disclosure and competitive advantage that ultimately translate to multiple indicators of financial performance, we plotted the moderation effects in Figure 4. It represents that family ownership strengthened the effect of perceived CSR and CSR disclosure on competitive advantage. Additionally, it can also be noticed that CSR perception and competitive advantage, CSR disclosure, and competitive advantage relationships are strengthened when family ownership is high than when it is low.
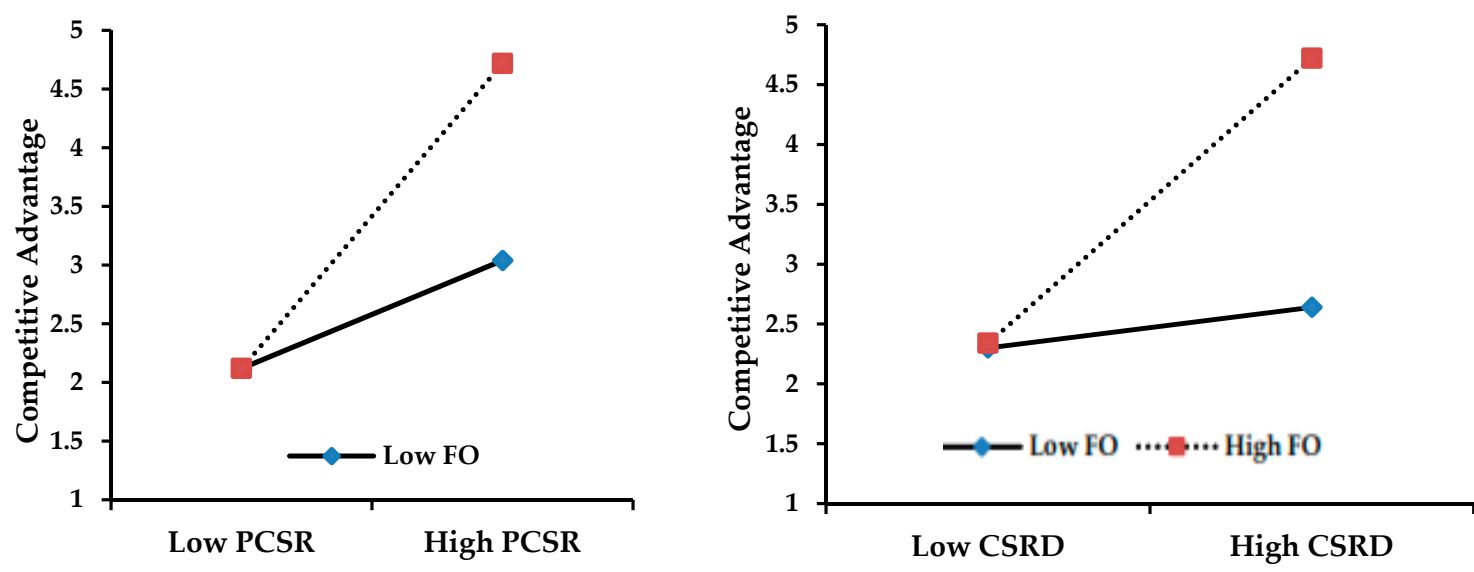

Figure 4. Moderation of family ownership.

Table 6 and Figure 3 showed the moderation effect of CEO narcissism on the impact of CSR perception and CSR disclosure on the perception of financial performance, Tobin Q, EPS and ROE through the mediation of competitive advantage. Hypothesis 4 stated that CEO narcissism strengthens the above-mentioned indirect relationship of CSR with firms' financial performance. Firstly, we tested for the interaction effect of CSR perception and CEO narcissism, as well as CSR disclosure and CEO narcissism on competitive advantage and found statistically significant positive effects: (Perceived CSR ${ }^{*} \mathrm{CEO}$ narcissism $=1.31$ ), 95\% CI [0.91, 1.87] and (CSR disclosure ${ }^{*} \mathrm{CEO}$ 
narcissism $=0.49), 95 \%$ CI $[0.03,0.61]$. Further, we found that CEO narcissism strengthened the impact of CSR perception on perceived financial performance through the mediated mechanism of competitive advantage, 0.03 (95\% CI [0.02, 0.09]), as it was statistically insignificant, 0.02 (95\% CI $[-0.01,0.04])$, as previously shown in Table 4.

Table 6. Moderation of CEO Narcissism.

\begin{tabular}{|c|c|c|c|}
\hline & Estimates & $95 \% C I$ & Remarks \\
\hline Perceived CSR ${ }^{*} \mathrm{CEON} \rightarrow \mathrm{CA}$ & 1.31 * & {$[0.91,1.87]$} & \\
\hline CSR Disclosure ${ }^{*} \mathrm{CEON} \rightarrow \mathrm{CA}$ & $0.49^{* *}$ & {$[0.03,0.61]$} & \\
\hline Perceived CSR ${ }^{*} \mathrm{CEON} \rightarrow \mathrm{CA} \rightarrow \mathrm{PFP}$ & $0.03^{* *}$ & {$[0.02,0.09]$} & $\mathrm{H}_{4:}$ Supported \\
\hline Perceived CSR ${ }^{*} \mathrm{CEON} \rightarrow \mathrm{CA} \rightarrow$ Tobin $\mathrm{Q}$ & $0.16^{*}$ & {$[0.15,0.39]$} & $\mathrm{H}_{4:}$ Supported \\
\hline Perceived CSR ${ }^{*} \mathrm{CEON} \rightarrow \mathrm{CA} \rightarrow$ EPS & $0.49 *$ & {$[0.11,1.22]$} & $\mathrm{H}_{4:}$ Supported \\
\hline Perceived CSR ${ }^{*} \mathrm{CEON} \rightarrow \mathrm{CA} \rightarrow \mathrm{ROE}$ & 0.38 * & {$[0.19,0.88]$} & $\mathrm{H}_{4:}$ Supported \\
\hline CSR Disclosure ${ }^{*} \mathrm{CEON} \rightarrow \mathrm{CA} \rightarrow \mathrm{PFP}$ & 0.01 & {$[-0.02,0.09]$} & ns \\
\hline CSR Disclosure* CEON $\rightarrow$ CA $\rightarrow$ Tobin Q & $0.06^{* *}$ & {$[0.03,0.10]$} & $\mathrm{H}_{4:}$ Supported \\
\hline CSR Disclosure $^{*}$ CEON $\rightarrow$ CA $\rightarrow$ EPS & $0.18 *$ & {$[0.06,0.23]$} & $\mathrm{H}_{4:}$ Supported \\
\hline CSR Disclosure* CEON $\rightarrow$ CA $\rightarrow$ ROE & $0.14 *$ & {$[0.04,0.29]$} & $\mathrm{H}_{4:}$ Supported \\
\hline
\end{tabular}

We also found that the relationships of perceived CSR with Tobin Q, EPS, and ROE mediated by competitive advantage are strengthened with the moderation of CEO narcissism: $0.16(95 \% \mathrm{CI}$ [0.15, 0.39]), 0.49 (95\% CI [0.11, 1.22]), 0.38 (95\% CI [0.19, 0.88]), respectively. Thus, Hypothesis 4 is supported. Moreover, we also found statistically significant effect of CSR disclosure with Tobin Q, earnings per share and return on equity mediated by competitive advantage is strengthen with the moderation of CEO narcissism 0.06 (95\% CI [0.03, 0.10]), 0.18 (95\% CI [0.06, 0.23]), 0.14 (95\% CI [0.04, 0.29]) respectively. This supported our Hypothesis 4. Conversely, the impact of CSR disclosure on perceived financial performance through the mediation of competitive advantage remained statistically insignificant: 0.01 (95\% CI [-0.02, 0.09]).

Moreover, for a better understanding of the CEO narcissism moderation effect, we plotted the moderation effects in Figure 5. It represented, CEO narcissism strengthened the impact of perceived CSR and CSR disclosure on competitive advantage. It can also be noticed in Figure 5 that the above-mentioned effects are strengthened at a high level of CEO narcissism than when it is low.
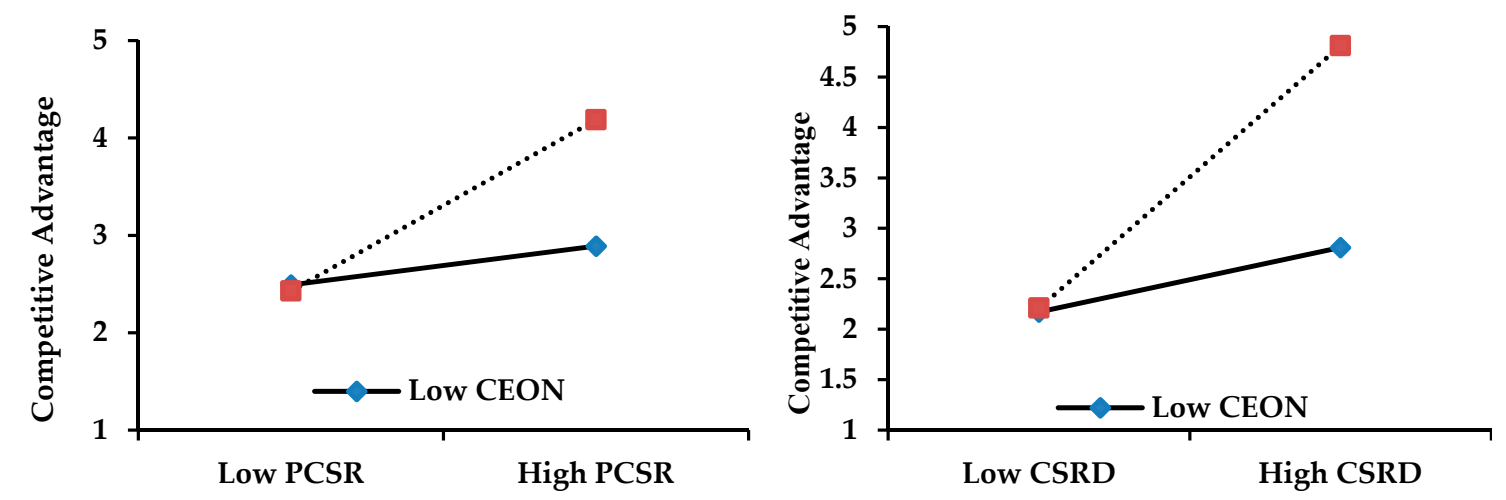

Figure 5. Moderation of CEO narcissism.

\section{Discussions and Conclusions}

The CSR and FFP relationship has remained the topic of importance for academic scholars and practitioners in the field of management and finance for the last few decades [1,8]. Recent calls for research on antecedents and consequences of CSR have drawn the attention of researchers worldwide and in developing economies in particular [42]. A vast stream of literature on the CSR and FFP 
relationship investigated the direct impact of CSR on FFP and found positive, negative, and even no effects $[13,70]$. However, these studies have not explained how CSR can be related to financial performance positively, negatively or neutrally. Accordingly, various attempts have been made to come up with the mechanisms and boundary conditions which can justify the direction of this relationship. But no final consensus has been established so far on the association of CSR with firms' financial performance due to inconsistent findings, and the debate is ongoing [3]. Most of the existing research has overlooked numerous mediators and boundary conditions to explaining CSR and FFP [28]. Moreover, existing studies have also used distinctive measures of CSR and financial performance, which may provide ambiguous findings [71].

Thus, the need of the hour is to investigate the CSR and FFP relationship by considering the factors that have been ignored or given less attention in the present literature. Further, it is also essential to investigate the multiple indicators of CSR and firms' financial performance within one framework. Therefore, this study aims to address these gaps in the existing research on CSR and FFP relationship by examining an essential mechanism and boundary conditions to explain how and when CSR is linked with FFP. This research intends to examine the impact of CSR on FFP with the mediation mechanism of competitive advantage and boundary conditions of CEO narcissism and family ownership. RBV is used to ground the underlying framework.

Specifically, this research advances the current debate of CSR and firms' financial performance relationship by collecting multi-source, multi-method data for various indicators of firms' CSR initiatives (CSR perception and disclosure) and financial performance (perception-, market-, and accounting-based) that have not been jointly investigated so far. Further, the mediation mechanism of competitive advantage by the theoretical lens of RBV is investigated. Additionally, the boundary conditions of family ownership and CEO narcissism further enhanced the significance of this research.

First, we investigated the direct impact of CSR perception and disclosure on perception, accounting, and market-based firms' financial performance. We found interesting and unique results across several indicators of CSR and FFP. For instance, there is a direct positive impact of CSR perception on perceived, accounting, and market-based financial performance. Our findings are in line with the existing literature on this relationship. For example, Waddock [13] and Akben-Selcuk [72] also reported similar results. Thus, our research validated studies that have reported a positive impact of CSR on FFP, in contrast with the neoclassical view, which suggested this relationship to be negative. This research also found a positive and statistically significant direct impact of CSR disclosure on perception-, accounting-, and market-based financial performance. These results also verified the existing studies on this relationship, such as Javeed [10] who found that CSR disclosure and accounting-based financial performance are directly and positively related. Further, our research also validated that CSR disclosure is strongly linked with accounting-based financial performance $[68,73,74]$.

Secondly, the present study also seeks to inspect the impact of CSR perception and CSR disclosure on FFP indicators through the mediation of competitive advantage, and we found partial mediation. Existing studies carried out by employing the resource-based view noted that sustainable competitive advantage plays an essential role in achieving a key aim of the corporation, which is to maximize financial performance $[8,75]$. Thus, the objective of various organizational strategies is to attain a sustainable competitive advantage. CSR is one of these strategies which intent to create a good standing for the firms in the massive competitive environment. Our findings validated the perspectives of the resource-based view and existing studies on this relationship. For example, Cantele [28] noted a positive and statistically significant effect of CSR perceptions on perceived financial performance through the mediation of competitive advantage. We also found a positive relationship, but it remained statistically insignificant.

There exists little evidence of the impact of CSR disclosure on competitive advantage, which ultimately translates into accounting- and market-based financial performance. We found partial mediation of competitive advantage on CSR disclosure and multiple indicators of financial performance relationship. Saeidi [8] also found partial mediation of competitive advantage on the 
effect of CSR disclosure on the perception of financial performance. Regarding the indirect impact of CSR disclosure on accounting and market-based indicators through the mediation of competitive advantage, it is not evident in the present literature. However, numerous studies have examined the direct effect of CSR disclosure on accounting- and market- based financial performance and noted positive relationship. Thus, further investigations are required to verify our findings.

We analyzed the moderation of family ownership of the effect of perceived CSR and CSR disclosure on the competitive advantage that, in turn, translate into perception-, market-, and accounting-based indicators. We found that family ownership strengthened this relationship. To date, we have not found any research that has investigated the boundary condition of family ownership on the above-mentioned relationship as most of the existing research is confined to direct effect; we showed that the CSR and FFP relationship is strengthened with the presence of family ownership.

Moreover, the originality and significance of this study are further enhanced by the boundary condition of CEO narcissism. We found that the impact of CSR perception and disclosure on the competitive advantage that ultimately translates to perception-, market-, and accounting-based FFP is strengthened by CEO narcissism. We noted that no research has so far investigated the moderation of CEO narcissism directly or indirectly of the association of CSR perceptions and disclosure with multiple indicators of financial performance or through the mediation of competitive advantage. Hu [76] and Grewatsch [16] recently called for research on CEO characteristics. The scarcity in the literature on this relationship is worse in emerging and developing countries particularly.

Specifically, we extended the ongoing CSR and financial performance debate in numerous ways, such as investigating the mediation mechanism of competitive advantage by underpinning a resource-based view and moderation of family ownership and CEO narcissism. Finally, we examined multiple indicators of CSR (perception and disclosure) and firms' financial performance (perception-, market-, and accounting-based) under one cohesive framework.

\subsection{Theoretical and Practical Implications}

This research makes numerous theoretical and practical contributions. For instance, this study progressed our current understandings of how CSR perception and disclosure provide a competitive advantage to the firms, which ultimately translated into the perception-, market-, and accounting-based indicators of financial performance. It also highlighted when the boundary conditions of family ownership and CEO narcissism influenced this above-said relationship of CSR and FFP. Academically, our research contributes to the CSR and FFP literature in various striking ways.

First, this research extends and confirms the current line of research on CSR and firms' financial performance relationship by analyzing the direct impact of multiple CSR indicators (CSR perception and disclosure) on multiple financial performance indicators (perception, market and accounting). To date, there exist no such studies that have examined these relationships together. Second, theoretically, this research validates the perspectives of the resource-based view, as we found that organizations can achieve competitive advantage by executing CSR as a value-creating strategy to achieve sustainable competitive advantage. While existing studies have also examined this mediation of competitive advantage on the CSR and FFP relationship, our research considered the mediation of competitive advantage between multiple indicators of CSR and FFP under one cohesive framework. This study also established that both CSR perception and disclosure provided sustainable competitive advantage to the firms. Third, the value of this study is extended with the boundary conditions of family ownership and CEO narcissism as well. We found that the existing literature overlooked the effect of these boundary conditions on indirect CSR and FFP relationship. Thus, in accordance with RBV, the present study proved that family ownership and CEO narcissism are such intangible resources that they are heterogeneous, immobile, valuable, rare, and inimitable. These resources assist firms in achieving sustainable competitive advantage that ultimately turns into firms' financial performance.

From a practical viewpoint, this research revealed various means through which managers may strategically concentrate on their policy implications regarding CSR. Firms can achieve sustainable 
competitive advantage by keeping in check their CSR perception and disclosure. Firms should also focus on their CEO's narcissism to attain their sustainable development objectives. Narcissism is usually considered a dark personality trait; however, here, for the CSR policy implications, it is proved to be strengthen the firms' CSR initiatives and competitive advantage relationship. The human resource management of firms should also align the recruitment process with firms' sustainability policies. For example, applicants can be evaluated on their personality traits, such as narcissism by asking, related questions at the time of the interview. Thus, when firms consider CSR as a value-creating strategy, they may prefer to appoint narcissistic individuals to achieve sustainable competitive advantage. Finally, managers must also give due attention to family ownership, as family ownership structure was found to positively influence the firms' CSR actions and competitive advantage relationship.

\subsection{Limitations and Future Directions}

This study focuses on firms' CSR perception and disclosure on FFP with the mediation mechanism of competitive advantage. It would be valuable to examine the impact of CSR perception and disclosure on financial performance by considering cross-level mediators and boundary conditions like employees' performance, leadership style. This research used cross-sectional data. It is recommended for further studies to collect longitudinal data. This research contributed to the resource-based view. Moreover, it is also suggested to investigate the relationship of CSR with FFP through other theoretical lenses such as social identity theory. It would be interesting to uncover the role of micro-level (employee-level) theory to derive a macro-level (firm-level) relationship. Thus, future studies must concentrate on multilevel aspects.

Author Contributions: Conceptualization, methodology, formal analysis and preparation of original draft, F.M., F.Q. and M.S.; Review and editing, A.A.-M.; Software and formal analysis, J.A., U.S. All authors have read and agreed to the published version of the manuscript.

Funding: No external funding was received.

Acknowledgments: We thank anonymous reviewers and the editors for their very useful recommendations.

Conflicts of Interest: We state no conflict of interest.

\section{References}

1. Wang, W.; Fu, Y.; Qiu, H.; Moore, J.H.; Wang, Z. Corporate social responsibility and employee outcomes: A moderated mediation model of organizational identification and moral identity. Front. Psychol. 2017, 8, 1906. [CrossRef]

2. Ashrafi, M.; Magnan, G.M.; Adams, M.; Walker, T.R. Understanding the Conceptual Evolutionary Path and Theoretical Underpinnings of Corporate Social Responsibility and Corporate Sustainability. Sustainability 2020, 12, 760. [CrossRef]

3. Xie, X.; Jia, Y.; Meng, X.; Li, C. Corporate social responsibility, customer satisfaction, and financial performance: The moderating effect of the institutional environment in two transition economies. J. Clean. Prod. 2017, 150, 26-39. [CrossRef]

4. Van Beurden, P.; Gössling, T. The worth of values-a literature review on the relation between corporate social and financial performance. J. Bus. Ethics. 2008, 82, 407. [CrossRef]

5. Mahmood, F.; Qadeer, F.; Abbas, Z.; Hussain, I.; Saleem, M.; Hussain, A.; Aman, J. Corporate Social Responsibility and Employees' Negative Behaviors under Abusive Supervision: A Multilevel Insight. Sustainability 2020, 12, 2647. [CrossRef]

6. Abbas, J.; Mahmood, S.; Ali, H.; Ali Raza, M.; Ali, G.; Aman, J.; Bano, S.; Nurunnabi, M. The Effects of Corporate Social Responsibility Practices and Environmental Factors through a Moderating Role of Social Media Marketing on Sustainable Performance of Business Firms. Sustainability 2019, 11, 3434. [CrossRef]

7. Herrera, J.; de las Heras-Rosas, C. Corporate social responsibility and human resource management: Towards sustainable business organizations. Sustainability 2020, 12, 841. [CrossRef] 
8. Saeidi, S.P.; Sofian, S.; Saeidi, P.; Saeidi, S.P.; Saaeidi, S.A. How does corporate social responsibility contribute to firm financial performance? The mediating role of competitive advantage, reputation, and customer satisfaction. J. Bus. Res. 2015, 68, 341-350. [CrossRef]

9. Wang, Y.; Berens, G. The impact of four types of corporate social performance on reputation and financial performance. J. Bus. Ethics. 2015, 131, 337-359. [CrossRef]

10. Javeed, S.A.; Lefen, L. An analysis of corporate social responsibility and firm performance with moderating effects of CEO power and ownership structure: A case study of the manufacturing sector of Pakistan. Sustainability 2019, 11, 248. [CrossRef]

11. Abdullah, M.I.; Ashraf, S.; Sarfraz, M. The organizational identification perspective of CSR on creative performance: The moderating role of creative self-efficacy. Sustainability 2017, 9, 2125. [CrossRef]

12. Shin, Y.; Thai, V.V. The impact of corporate social responsibility on customer satisfaction, relationship maintenance and loyalty in the shipping industry. Corp. Soc. Responsib. Environ. Manag. 2015, 22, 381-392. [CrossRef]

13. Waddock, S.A.; Graves, S.B. The corporate social performance-financial performance link. Strateg. Manag. 1997, 18, 303-319. [CrossRef]

14. Trumpp, C.; Guenther, T. Too little or too much? Exploring U-shaped relationships between corporate environmental performance and corporate financial performance. Bus. Strat. Environ. 2017, 26, 49-68. [CrossRef]

15. Ali, H.Y.; Danish, R.Q.; Asrar-ul-Haq, M. How corporate social responsibility boosts firm financial performance: The mediating role of corporate image and customer satisfaction. Corp. Soc. Responsib. Environ. Manag. 2019, 27, 166-177. [CrossRef]

16. Grewatsch, S.; Kleindienst, I. When does it pay to be good? Moderators and mediators in the corporate sustainability-corporate financial performance relationship: A critical review. J. Bus. Ethics 2017, 145, 383-416. [CrossRef]

17. Wang, Q.; Dou, J.; Jia, S. A meta-analytic review of corporate social responsibility and corporate financial performance: The moderating effect of contextual factors. Bus. Soc. 2016, 55, 1083-1121. [CrossRef]

18. Barney, J.B. The resource-based theory of the firm. Organ. Sci. 1996, 7, 469. [CrossRef]

19. McWilliams, A.; Siegel, D.S.; Wright, P.M. Corporate social responsibility: Strategic implications. J. Manag. Stud. 2006, 43, 1-18. [CrossRef]

20. Branco, M.C.; Rodrigues, L.L. Corporate social responsibility and resource-based perspectives. J. Bus. Ethics. 2006, 69, 111-132. [CrossRef]

21. Shahzad, F.; Rehman, I.U.; Nawaz, F.; Nawab, N. Does family control explain why corporate social responsibility affects investment efficiency? Corp. Soc. Responsib. Environ. Manag. 2018, 25, 880-888. [CrossRef]

22. Aguinis, H. Organizational responsibility: Doing good and doing well. APA Handb. Ind. Organ. Psychol. 2011, 3, 855-879.

23. Anser, M.K.; Zhang, Z.; Kanwal, L. Moderating effect of innovation on corporate social responsibility and firm performance in realm of sustainable development. Corp. Soc. Responsib. Environ. Manag. 2018, 25, 799-806. [CrossRef]

24. Lin, C.-H.; Yang, H.-L.; Liou, D.-Y. The impact of corporate social responsibility on financial performance: Evidence from business in Taiwan. Technol. Soc. 2009, 31, 56-63. [CrossRef]

25. Ruggiero, P.; Cupertino, S. CSR strategic approach, financial resources and corporate social performance: The mediating effect of innovation. Sustainability 2018, 10, 3611. [CrossRef]

26. Lu, W.; Chau, K.; Wang, H.; Pan, W. A decade's debate on the nexus between corporate social and corporate financial performance: A critical review of empirical studies 2002-2011. J. Clean. Prod. 2014, 79, 195-206. [CrossRef]

27. Chang, C.-H. The influence of corporate environmental ethics on competitive advantage: The mediation role of green innovation. J. Bus. Ethics. 2011, 104, 361-370. [CrossRef]

28. Cantele, S.; Zardini, A. Is sustainability a competitive advantage for small businesses? An empirical analysis of possible mediators in the sustainability-financial performance relationship. J. Clean. Prod. 2018, 182, 166-176. [CrossRef]

29. Kim, K.-H.; Kim, M.; Qian, C. Effects of corporate social responsibility on corporate financial performance: A competitive-action perspective. J. Manag. 2018, 44, 1097-1118. [CrossRef] 
30. McWilliams, A.; Siegel, D.S. Creating and capturing value: Strategic corporate social responsibility, resource-based theory, and sustainable competitive advantage. J. Manag. 2011, 37, 1480-1495. [CrossRef]

31. Rhou, Y.; Singal, M.; Koh, Y. CSR and financial performance: The role of CSR awareness in the restaurant industry. Int. J. Hosp. Manag. 2016, 57, 30-39. [CrossRef]

32. Marin, L.; Martín, P.J.; Rubio, A. Doing good and different! The mediation effect of innovation and investment on the influence of CSR on competitiveness. Corp. Soc. Responsib. Environ. Manag. 2017, 24, 159-171. [CrossRef]

33. Marín, L.; Rubio, A.; de Maya, S.R. Competitiveness as a strategic outcome of corporate social responsibility. Corp. Soc. Responsib. Environ. Manag. 2012, 19, 364-376. [CrossRef]

34. Carney, M. Corporate governance and competitive advantage in family-controlled firms. Entrep. Theory Pr. 2005, 29, 249-265. [CrossRef]

35. Block, J.H.; Wagner, M. The effect of family ownership on different dimensions of corporate social responsibility: Evidence from large US firms. Bus. Strat. Environ. 2014, 23, 475-492. [CrossRef]

36. Zellweger, T.M.; Nason, R.S.; Nordqvist, M.; Brush, C.G. Why do family firms strive for nonfinancial goals? An organizational identity perspective. Entrep. Theory Pr. 2013, 37, 229-248. [CrossRef]

37. Campbell, W.K.; Hoffman, B.J.; Campbell, S.M.; Marchisio, G. Narcissism in organizational contexts. Hum. Resour. Manag. Rev. 2011, 21, 268-284. [CrossRef]

38. Tang, Y.; Mack, D.Z.; Chen, G. The differential effects of CEO narcissism and hubris on corporate social responsibility. Strateg. Manag. 2018, 39, 1370-1387. [CrossRef]

39. Petrenko, O.V.; Aime, F.; Ridge, J.; Hill, A. Corporate social responsibility or CEO narcissism? CSR motivations and organizational performance. Strateg. Manag. 2016, 37, 262-279. [CrossRef]

40. Podsakoff, P.M.; MacKenzie, S.B.; Lee, J.-Y.; Podsakoff, N.P. Common method biases in behavioral research: A critical review of the literature and recommended remedies. J. Appl. Psychol. 2003, 88, 879. [CrossRef]

41. Jones, D.A.; Newman, A.; Shao, R.; Cooke, F.L. Advances in employee-focused micro-level research on corporate social responsibility: Situating new contributions within the current state of the literature. J. Bus. Ethics. 2019, 157, 293-302. [CrossRef]

42. John, A.; Qadeer, F.; Shahzadi, G.; Jia, F. Getting paid to be good: How and when employees respond to corporate social responsibility? J. Clean. Prod. 2019, 215, 784-795. [CrossRef]

43. Mishra, S.; Suar, D. Does corporate social responsibility influence firm performance of Indian companies? J. Bus. Ethics. 2010, 95, 571-601. [CrossRef]

44. Maignan, I.; Ferrell, O. Antecedents and benefits of corporate citizenship: An investigation of French businesses. J. Bus. Res. 2001, 51, 37-51. [CrossRef]

45. Khan, A.; Muttakin, M.B.; Siddiqui, J. Corporate governance and corporate social responsibility disclosures: Evidence from an emerging economy. J. Bus. Ethics. 2013, 114, 207-223. [CrossRef]

46. Blasi, S.; Caporin, M.; Fontini, F. A multidimensional analysis of the relationship between corporate social responsibility and firms' economic performance. Ecol. Econ. 2018, 147, 218-229. [CrossRef]

47. Kansal, M.; Joshi, M.; Batra, G.S. Determinants of corporate social responsibility disclosures: Evidence from India. Adv. Account. 2014, 30, 217-229. [CrossRef]

48. Yuen, K.F.; Thai, V.V.; Wong, Y.D.; Wang, X. Interaction impacts of corporate social responsibility and service quality on shipping firms' performance. Transport. Res. A-Pol. 2018, 113, 397-409. [CrossRef]

49. Malik, M.S.; Kanwal, L. Impact of corporate social responsibility disclosure on financial performance: Case study of listed pharmaceutical firms of Pakistan. J. Bus. Ethics. 2018, 150, 69-78. [CrossRef]

50. Galvin, B.M.; Lange, D.; Ashforth, B.E. Narcissistic organizational identification: Seeing oneself as central to the organization's identity. Acad. Manag. Rev. 2015, 40,163-181. [CrossRef]

51. Zhao, Z.; Meng, F.; He, Y.; Gu, Z. The influence of corporate social responsibility on competitive advantage with multiple mediations from social capital and dynamic capabilities. Sustainability 2019, 11, 218. [CrossRef]

52. Protogerou, A.; Caloghirou, Y.; Lioukas, S. Dynamic capabilities and their indirect impact on firm performance. Ind. Corp. Chang. 2012, 21, 615-647. [CrossRef]

53. Chen, C.; Zhou, Z. Research on the Influence of Corporate Social Responsibility on the Persistence of Corporate Competitive Advantage. Forum Sci. Technol. China 2014, 5, 68-73.

54. Chen, Y.-S.; Lai, S.-B.; Wen, C.-T. The influence of green innovation performance on corporate advantage in Taiwan. J. Bus. Ethics. 2006, 67, 331-339. [CrossRef] 
55. Resick, C.J.; Whitman, D.S.; Weingarden, S.M.; Hiller, N.J. The bright-side and the dark-side of CEO personality: Examining core self-evaluations, narcissism, transformational leadership, and strategic influence. J. Appl. Psychol. 2009, 94, 1365. [CrossRef]

56. Hair, J.F.; Black, W.C.; Babin, B.J.; Anderson, R.E.; Tatham, R.L. Multivariate Data Analysis; Prentice Hall: Upper Saddle River, NJ, USA, 1998.

57. Chan, D. Functional relations among constructs in the same content domain at different levels of analysis: A typology of composition models. J. Appl. Psychol. 1998, 83, 234. [CrossRef]

58. Farh, C.I.; Chen, Z. Beyond the individual victim: Multilevel consequences of abusive supervision in teams. J. Appl. Psychol. 2014, 99, 1074. [CrossRef]

59. Preacher, K.J.; Zhang, Z.; Zyphur, M.J. Alternative methods for assessing mediation in multilevel data: The advantages of multilevel SEM. Struct. Equ. Model. 2011, 18, 161-182. [CrossRef]

60. James, L.R. Aggregation bias in estimates of perceptual agreement. J. Appl. Psychol. 1982, 67, 219. [CrossRef]

61. James, L.R.; Demaree, R.G.; Wolf, G. rwg: An assessment of within-group interrater agreement. J. Appl. Psychol. 1993, 78, 306. [CrossRef]

62. Saleem, M.; Qadeer, F.; Mahmood, F.; Ariza-Montes, A.; Han, H. Ethical Leadership and Employee Green Behavior: A Multilevel Moderated Mediation Analysis. Sustainability 2020, 12, 3314. [CrossRef]

63. Kim, A.; Kim, Y.; Han, K.; Jackson, S.E.; Ployhart, R.E. Multilevel influences on voluntary workplace green behavior: Individual differences, leader behavior, and coworker advocacy. J. Manag. 2017, 43, 1335-1358. [CrossRef]

64. Zaefarian, G.; Kadile, V.; Henneberg, S.C.; Leischnig, A. Endogeneity bias in marketing research: Problem, causes and remedies. Ind. Mark. Manag. 2017, 65, 39-46. [CrossRef]

65. Wooldridge, J.M. Introductory Econometrics: A Modern Approach; Nelson Education: Toronto, ON, Canada, 2016.

66. Tang, T.; Fang, E.; Wang, F. Is neutral really neutral? The effects of neutral user-generated content on product sales. J. Mark. 2014, 78, 41-58. [CrossRef]

67. Surroca, J.; Tribó, J.A. Managerial entrenchment and corporate social performance. J. Bus. Finance. Account. 2008, 35, 748-789. [CrossRef]

68. Cho, S.J.; Chung, C.Y.; Young, J. Study on the Relationship between CSR and Financial Performance. Sustainability 2019, 11, 343. [CrossRef]

69. Nunnally, J.C.; Bernstein, I. Psychometric Theory; McGraw-Hill: New York, NY, USA, 1978.

70. Orlitzky, M. Corporate social responsibility, noise, and stock market volatility. Acad. Manag. Perspect. 2013, 27, 238-254. [CrossRef]

71. Gallardo-Vázquez, D.; Barroso-Méndez, M.J.; Pajuelo-Moreno, M.L.; Sánchez-Meca, J. Corporate social responsibility disclosure and performance: A meta-analytic approach. Sustainability 2019, 11, 1115. [CrossRef]

72. Akben-Selcuk, E. Corporate social responsibility and financial performance: The moderating role of ownership concentration in Turkey. Sustainability 2019, 11, 3643. [CrossRef]

73. Kim, J.; Cho, K.; Park, C.K. Does CSR Assurance Affect the Relationship between CSR Performance and Financial Performance? Sustainability 2019, 11, 5682. [CrossRef]

74. Allouche, J.; Laroche, P. A meta-analytical investigation of the relationship between corporate social and financial performance. Revue. Gestion. Res. Hum. 2005, 5, 8-41.

75. Majeed, S. The impact of competitive advantage on organizational performance. Eur. J. Busi. Manag. 2011, 3, 191-196.

76. Hu, W.; Du, J.; Zhang, W. Corporate Social Responsibility Information Disclosure and Innovation Sustainability: Evidence from China. Sustainability 2020, 12, 409. [CrossRef]

(C) 2020 by the authors. Licensee MDPI, Basel, Switzerland. This article is an open access article distributed under the terms and conditions of the Creative Commons Attribution (CC BY) license (http://creativecommons.org/licenses/by/4.0/). 